\title{
A STUDY OF THE FISH COMMUNITY STRUCTURE IN A TIDAL CREEK
}

\author{
SPACH, H. L., SANTOS, C., GODEFROID, R. S., \\ NARDI, $M$. and CUNHA, F. \\ Centro de Estudos do Mar, Universidade Federal do Paraná, C.P. 50002, CEP 83255-000, \\ Pontal do Sul, PR, Brazil \\ Correspondence to: Henry Louis Spach, Centro de Estudos do Mar, Universidade Federal do Paraná, \\ C.P. 50002, CEP 83255-000, Pontal do Sul, PR, Brazil, e-mail: hlspach@cem.ufpr.br \\ Received September 12, 2002 - Accepted January 24, 2003 - Distributed May 31, 2004
}

(With 5 figures)

\begin{abstract}
The fish assemblage in a mangrove tidal creek was studied in monthly collections between August 1998 and July 1999 in the quadrature low tide and high tide, using a fyke net of $30 \mathrm{~m} \times 1.5 \mathrm{~m}$ and meshes of 8 and $10 \mathrm{~mm}$. Simultaneously with the biological collections, temperature, salinity, $\mathrm{pH}$, water transparency, and current speed data were obtained. The collections resulted in the capture of 36,873 fish representing 22 families and 52 species. Immature individuals abounded (63.8\%), and among the adult specimens there was a larger number of females. The species Anchoa parva, Harengula clupeola, Genidens genidens, and Bairdiella ronchus, contributed to $84.9 \%$ of the total capture of fish, however the contribution in mass was of $55.2 \%$, indicating a predominance of small individuals. A smaller number of fish and species seem to occupy the area in the period between August and December, in comparison to the period between February and July, when the larger aggregations appear, mainly of the species Anchoa parva, Harengula clupeola, Opisthonema oglinum, Genidens genidens, Diapterus rhombeus, and Bairdiella ronchus. The environmental factors, $\mathrm{pH}$, water transparency, and rainfall seem to have an influence in the structure of the observed biological patterns.
\end{abstract}

Key words: tidal creek, fishes, diversity, abundance, temporal variation.

\section{RESUMO}

\section{Um estudo sobre a estrutura da comunidade de peixes de um rio de maré}

A comunidade de peixes em um rio de maré de mangue foi estudada em coletas mensais entre agosto de 1998 e julho de 1999 na baixa-mar e preamar de quadratura, utilizando-se uma rede fixa tipo "fyke" com $30 \mathrm{~m} \times 1,5 \mathrm{~m}$ e malhas de $8 \mathrm{e} 10 \mathrm{~mm}$. Simultaneamente às coletas biológicas, foram registrados dados de temperatura, salinidade, $\mathrm{pH}$, transparência da água e velocidade da corrente. As coletas resultaram na captura de 36.873 peixes, representando 22 famílias e 52 espécies. Predominaram indivíduos imaturos $(63,8 \%)$ e as fêmeas, entre os adultos. As espécies Anchoa parva, Harengula clupeola, Genidens genidens e Bairdiella ronchus constituíram $84,9 \%$ da captura total de peixes, no entanto, a participação em peso foi de $55,2 \%$, indicando o predomínio de indivíduos de pequeno porte. Um menor número de peixes e espécies parece ocupar a área no período entre agosto e dezembro, comparado ao período entre fevereiro e julho, quando aparecem os maiores agregados, principalmente das espécies Anchoa parva, Harengula clupeola, Opisthonema oglinum, Genidens genidens, Diapterus rhombeus e Bairdiella ronchus. O pH, a transparência da água e a pluviosidade parecem influenciar a estruturação dos padrões biológicos observados.

Palavras-chave: rios de maré, peixes, diversidade, abundância, variabilidade temporal. 


\section{INTRODUCTION}

In estuaries, several intertidal and subtidal environments such as salt marshes, mangroves, tidal creeks, and tidal flats, offer an abundance and great diversity of food resources, protection against predation, and other favorable environmental conditions for the growth and survival of fish (Paterson \& Whitfield, 2000). These conditions favor the presence of large populations of fish in these shallow aquatic environments along the margin of estuaries (Rozas \& Zimmerman, 2000; Vidy, 2000).

These populations are dominated by juveniles of marine species and contain few resident species or occasional visitors. They show a wide temporal variation in their species composition due to the environmental dynamics and migratory nature of most of the fish, as well as to the connection between the estuarine habitats because of their proximity and tidal flow (Rozas \& Zimmerman, 2000).

The tidal creeks are courses of water that show a meandering route and a reduced self-debit, which drain the restinga formations, mangroves, and salt marshes. Their debit is strongly affected by the tide, and on a smaller scale by the wind, average water level, and coastal circulation.

In spite of the importance of these channels in the life cycle of the fish, most of the information available in the literature refers to the tide channels that connect the surface of the salt marshes with the estuarine waters of the main body (Cattrijsse et al., 1994; Desmond et al., 2000). In addition, there is little information on the ichthyofauna of mangrove tidal creeks (Robertson \& Duke, 1990; Vendel, 1997; Barletta, 1999).

The general objective of this study was to identify the species and temporal variation in the abundance and composition of the fish assemblage, community attributes $\left(\mathrm{D}, \mathrm{H}^{\prime}, \mathrm{J}\right)$, and the influence of environmental factors in the structure of the observed biological patterns in a tidal creek located on the continental margin of the euhaline section of Paranaguá Bay, Paraná.

\section{MATERIAL AND METHODS}

\section{Study area}

The present study was carried out in Gamboa do Baguaçu, located on the south margin of the euhaline section of Paranaguá Bay, coordinates $25^{\circ} 33^{\prime} 03^{\prime \prime} \mathrm{S}$ and $48^{\circ} 23^{\prime} 05^{\prime \prime} \mathrm{W}$ (Fig. 1). This channel is divided into two sub-channels, one with an extension of approximately $1.9 \mathrm{~km}$ and the other of $1.0 \mathrm{~km}$, and a depth varying from 0.5 to 5.0 meters. The mangrove drained by this tidal channel has about 43 ha and its vegetation is composed of Laguncularia racemosa, Rhizophora mangle, Avicenia shaweriana, with external banks of Spartina alterniflora. Its sediment is predominantly sandy, and to a smaller extent there are sandy-silt and silty-sand sediments. The predominance of sandy fractions indicates that it is highenergy area, due to its proximity to the bar that provides access to Paranaguá Bay (Sessegolo, 1997).

\section{Sampling design}

The sampling was done between August 1998 and July 1999, in the low and high quadrature (waning moon) tide, using a fyke net of $30 \times 1.5$ $\mathrm{m}$, and a mesh of $10 \mathrm{~mm}$ in the wings and $8 \mathrm{~mm}$ in the bag. On every collection day, two fyke nets were mounted. During high tide, the nets were installed facing the estuary and blocking the lateral channel and the margin of the main channel, in order to capture fish entering the channel along with the tide. To capture fish during low tide, one net was installed against the vegetation, on the margin of the mangrove, while the other blocked the main channel facing away from the estuary. Every hour, during high and low tide, water temperature, salinity, $\mathrm{pH}$, water transparency, and current speed data were obtained. The rainfall data were obtained from the meteorological station located at Centro de Estudos do Mar, UFPR. After identifying the fish, their weight (g), standard and total length ( $\mathrm{mm})$, and, whenever possible, sex and stage of gonadal maturity were obtained.

\section{Data analysis}

To identify the patterns of environmental variation and in the composition and abundance of the fish assemblage, the data was 4 th root transformed and tested for homogeneity of variance (Bartelett's test) and normal distribution (Kolmogorov-Smirnov's test). A unifactorial analysis of variance and the a posteriori test for least significant difference (LSD) (Sokal \& Rohlf, 1995), were used to compare the monthly averages of the physical-chemical parameters, the monthly 
and group averages of the months defined by cluster analysis (normal method), the number of species, number of fish, biomass, Margalef's species richness index, Shannon-Wiener's species diversity (number and weight) index, and Pielou's evenness index (Ludwig \& Reynolds, 1988). Where any assumption of ANOVA was not met, Kruskal-Wallis's non parametric statistics were used (Conover, 1990; Sokal \& Rohlf, 1995).

Cluster analysis (inverse mode) and nonmetric multidimensional scaling (MDS) were used to identify the species assemblages. The 19 most abundant and frequent species ( $>1 \%$ of the total capture or present in at least 6 months of collection) were grouped considering the monthly abundance data $4^{\text {th }}$ root transformed. The temporal structure of the assemblage was identified using the cluster analyses (normal mode) and nonmetric multidimensional scaling (MDS) with the species as attributes. The similarity between the attributes was calculated using the similarity coefficient of Bray-Curtis and the cluster-grouping method by the unweighted pair- group mean arithmetic linking method (UPGMA) (Ludwig \& Reynolds, 1988).

The analysis of similarity of percentages (SIMPER) was used to identify which species were mainly responsible for the similarities inside each group of months defined by cluster analysis and for the dissimilarities among these groups. The BIOENV routine was used to relate the observed biological patterns to the observed environmental pattern, considering the individual and combined environmental parameters. This routine selects environmental variables best explaining community pattern, by maximizing a rank correlation (Spearman coefficient) between biotic and abiotic similarity matrices (Clarke \& Warwick, 1994).

The analyses were made with the statistical programs Statistica, version 5.1 (Statsoft Corp., United States), and PRIMER, version 4.0 (Plymouth Marine Laboratory, England). The seasons of the year were defined as follows: September to November = spring; December to February = summer; March to May = autumn; and June to August $=$ winter.

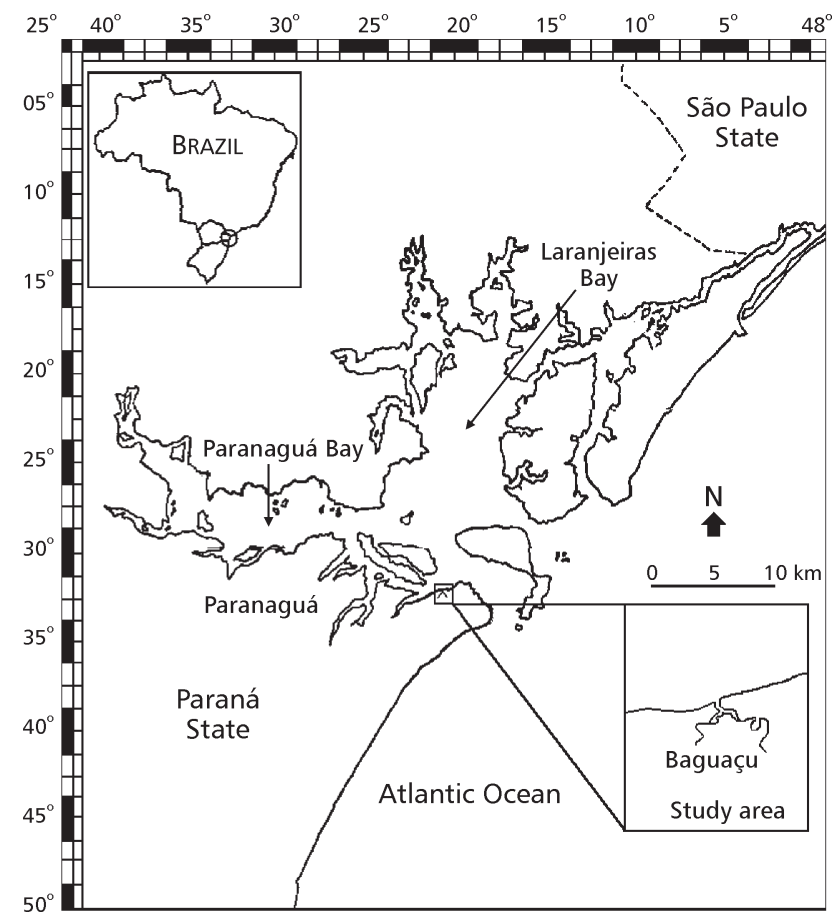

Fig. 1 - Map of Paraná coast, showing the sampling point in the Baguaçu tidal creek. 


\section{RESULTS}

\section{Environmental parameters}

The temperature presented a seasonal pattern, with significantly larger averages in the summer and beginning of autumn; intermediary ones in October, November, April, and May; and the smallest ones in winter and the beginning of spring (Fig. 2A). In the area, salinity was significantly smaller in February and November, with maximums in June and December, and intermediary mean values, with no statistical differences between them, from the middle of winter to the middle of spring, in January, and in autumn (Fig. 2B). An increase in the mean $\mathrm{pH}$ was observed from the end of spring to the middle of winter, followed by a decrease during the rest of winter and spring (Fig. 2C). Statistically, the mean $\mathrm{pH}$ in November was smaller than in the rest of the year, and greater from May to July in comparison to spring and from the middle of summer to the beginning of autumn. During the whole sample period, the water transparency values were significantly larger in December and May, and in June and July when compared to April, August, and November, although there was no significant difference between the end of winter and the end of spring, and the middle of summer and the middle of autumn (Fig. 2D). The mean current speed increased from the end of spring to the beginning of winter, and then decreased until August and showed little variation in spring. The mean values observed in June and July were only significantly larger than those registered between August and January, and there was no significant difference between the averages of the other months (Fig. 2E). The differences observed among the monthly rainfall averages were not significant (Fig. 2F).

\section{Ichthyofauna}

The monthly collections made throughout the year resulted in the capture of 36,873 fish from 52 species (Table 1). The ichthyofauna of Baguaçu tidal creek was dominated by both immature fish $(63.8 \%)$ and females (66.1\%). Twenty-four species present in the area were found only in the juvenile stage, 26 in the juvenile and adult stages, and two had only adult individuals. Moreover, the ichthyofauna was characterized by the largest species diversity in the families Carangidae and Sciaenidae (six species) and Engraulidae (five species) and by being dominated by some species of economic interest to commercial fishing (Anchoa parva, Anchoa tricolor, Harengula clupeola, Genidens genidens, Bairdiella ronchus, Sphoeroides greeleyi, and Sphoeroides testudineus) which always contributed individually and made up more than $2 \%$ of the capture. The great majority of the captured fish (58.7\%) belonged to the species $A$. parva that was not, however, present in all the months studied. Only the species B. ronchus, Citharichthys spilopterus, S. greeleyi, and $S$. testudineus were present in every month throughout collection. Together, the species A. parva, H. clupeola, G. genidens, and B. ronchus contributed with $84.9 \%$ of the total capture of fish, however with only $55.2 \%$ of the biomass, indicating that smaller fish predominated in the population (standard length: 50 to $100 \mathrm{~mm}$ ). The structure of the assemblage in number was relatively different to the structure in weight, being affected by the capture of larger individuals of S. testudineus (standard length: 50 to $150 \mathrm{~mm}$ ), B. ronchus (standard length: 80 to $140 \mathrm{~mm}$ ), and G. genidens (standard length: 50 to $150 \mathrm{~mm}$ ), and of smaller specimens of $A$. parva (standard length: 50 to $65 \mathrm{~mm}$ ) and of H. clupeola (standard length: 50 to $80 \mathrm{~mm}$ ). Therefore, A. parva, that dominated the captures in number (58.7\%), was the third main contributor in terms of biomass $(16.0 \%)$ and $\mathrm{S}$. testudineus, the fifth species captured numerically, was the species that most contributed to the structure in weight (30.6\%).

\section{Temporal variation}

The mean number of species was significantly lower from the end of winter to the end of spring, and the largest averages occured from the middle of summer to the beginning of winter, mainly in January and April (Fig. 3, Table 2). The number of fish in the samples was, on average, significantly greater from the middle of autumn to the beginning of winter, and the smallest averages occurred from the end of winter to the beginning of summer (Fig. 3 , Table 2). No significant difference was verified between the monthly capture averages in weight, species richness, and diversity (number and weight), however, except for the diversity, the values for the capture in weight and richness tended to be smaller from the end of winter to the middle of spring (Fig. 3, Table 2). Different from the other biological parameters, the mean evenness was larger from August to the beginning of summer, and presented smaller values between summer and winter, with the smallest average for the whole collection period occurring in June (Fig. 3, Table 2). 

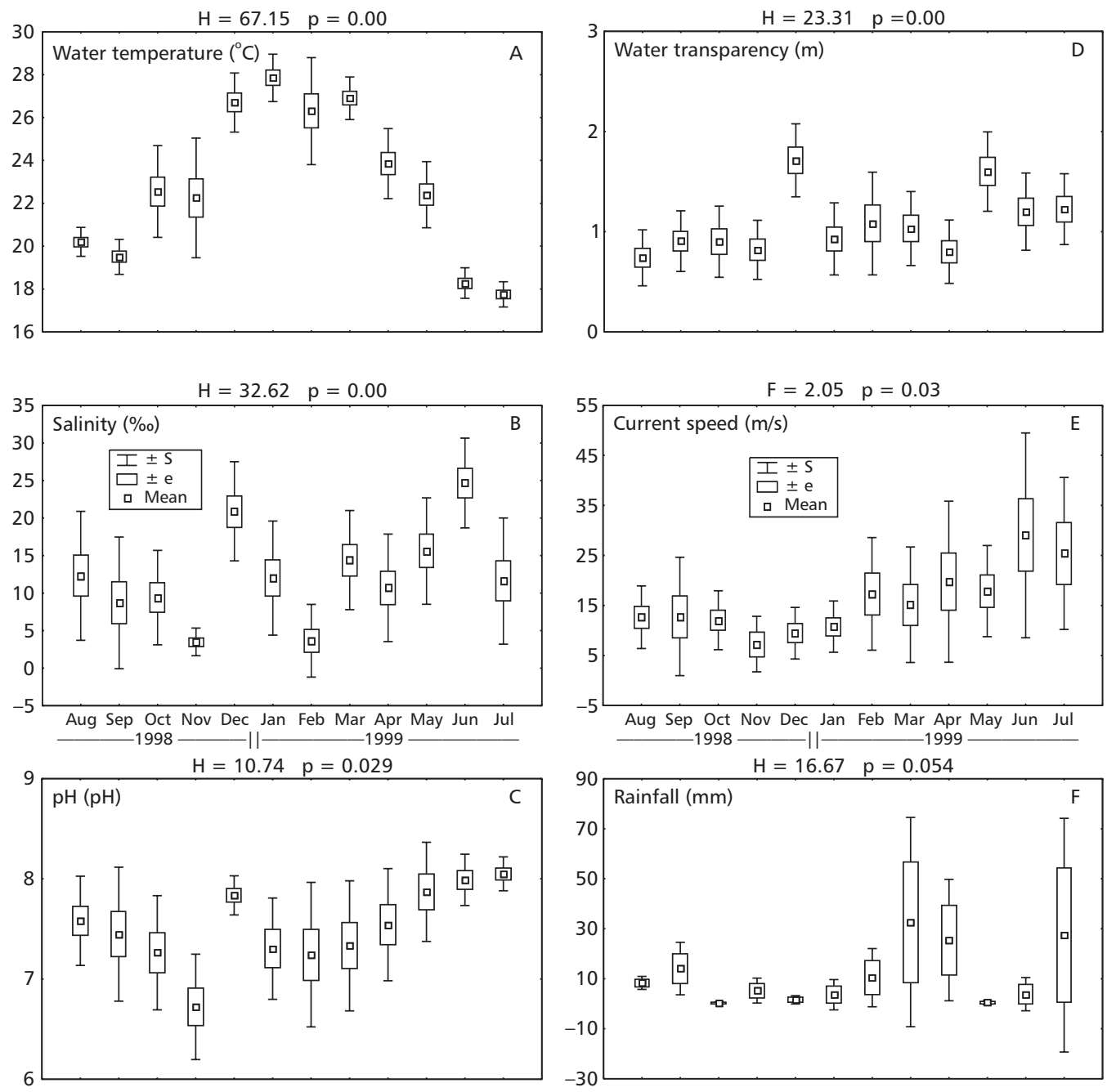

Fig. 2 - Monthly variation in the average of the water temperature, salinity, $\mathrm{pH}$, water transparency, current speed and rainfall, during the sampling period in the Baguaçu tidal creek.

Based on the density of the 23 main taxa, the cluster analysis separated the months of collection into two large groups, united at the similarity level of $68 \%$ (Fig. 4). Group A, united the months of August, September, October, November, and December at the similarity level of $71 \%$ and presented the smallest mean captures in number of species, number of fish, and biomass; the smallest values of species richness; and the largest values of evenness (Table 2). The second group (B), made up of the months February, March, April, May, June, and July united at the similarity level of $68.5 \%$, presented the largest captures in number of species, number of fish, biomass, and richness, and the smallest evenness values (Table 2). Group B is formed by two subgroups, the first with the months of February, March, and July united at the similarity level of $70.8 \%$, and the other formed by the months of April, May, and June united at the similarity level of $80.3 \%$. The month of January did not differ statistically from group B in any of the biological parameters considered and was only similar to the months of group A with regard to the capture in weight and evenness. In the nonmetric multidimensional scaling (MDS), the separation of the months into the first two dimensions corresponds to the pattern generated by cluster analysis. The stress of 0.092 indicates that the similarities are appropriately represented by the distances in the plain (Fig. 4). 
TABLE 1

Species composition and number of fish in the monthly captures in the Baguaçu tidel creek (\% of total capture).

\begin{tabular}{|c|c|c|c|c|c|c|c|c|c|c|c|c|c|}
\hline & Aug & Sep & Oct & Nov & Dec & Jan & Feb & Mar & Apr & May & Jun & Jul & $\%$ \\
\hline Anchoa lyolepis & 0 & 0 & 0 & 0 & 0 & 0 & 87 & 4 & 8 & 0 & 6 & 0 & 0.3 \\
\hline Anchoa parva & 62 & 0 & 0 & 0 & 1 & 3 & 7183 & 19 & 3685 & 1982 & 8124 & 583 & 58.7 \\
\hline Anchoa tricolor & 0 & 0 & 7 & 12 & 0 & 2 & 0 & 2 & 334 & 0 & 453 & 1 & 2.2 \\
\hline Cetengraulis edentulus & 0 & 0 & 0 & 0 & 0 & 1 & 0 & 1 & 0 & 0 & 0 & 0 & 0.0 \\
\hline Lycengraulis grossidens & 6 & 6 & 3 & 1 & 1 & 69 & 0 & 0 & 7 & 16 & 8 & 2 & 0.3 \\
\hline Harengula clupeola & 0 & 2 & 2 & 30 & 127 & 19 & 68 & 178 & 734 & 2215 & 284 & 115 & 10.2 \\
\hline Opisthonema oglinum & 0 & 0 & 0 & 0 & 0 & 5 & 11 & 3 & 6 & 24 & 45 & 1 & 0.3 \\
\hline Sardinella brasiliensis & 0 & 2 & 0 & 0 & 1 & 0 & 0 & 10 & 6 & 51 & 3 & 8 & 0.2 \\
\hline Genidens genidens & 0 & 1 & 0 & 1 & 119 & 746 & 13 & 1 & 1566 & 38 & 25 & 1 & 6.8 \\
\hline Mugil curema & 2 & 0 & 0 & 0 & 0 & 7 & 0 & 0 & 5 & 0 & 0 & 0 & 0.0 \\
\hline Mugil gaimardianus & 0 & 0 & 0 & 0 & 0 & 1 & 0 & 0 & 0 & 0 & 0 & 0 & 0.0 \\
\hline Mugil incilis & 0 & 0 & 0 & 0 & 0 & 1 & 0 & 0 & 0 & 0 & 0 & 0 & 0.0 \\
\hline Mugil sp. & 0 & 0 & 0 & 0 & 0 & 0 & 1 & 0 & 0 & 1 & 0 & 0 & 0.0 \\
\hline Atherinella brasiliensis & 16 & 5 & 35 & 1 & 50 & 1 & 0 & 2 & 64 & 49 & 64 & 10 & 0.8 \\
\hline Strongylura sp. & 0 & 0 & 0 & 0 & 0 & 0 & 0 & 0 & 0 & 0 & 1 & 0 & 0.0 \\
\hline Hemiramphus brasiliensis & 0 & 0 & 1 & 1 & 0 & 0 & 0 & 0 & 0 & 6 & 0 & 0 & 0.0 \\
\hline Hyporhamphus unifasciatus & 6 & 10 & 1 & 0 & 3 & 0 & 0 & 0 & 4 & 2 & 2 & 1 & 0.1 \\
\hline Poecilia vivipara & 0 & 0 & 0 & 17 & 0 & 1 & 0 & 0 & 0 & 0 & 0 & 0 & 0.0 \\
\hline Centropomus parallelus & 0 & 0 & 17 & 6 & 4 & 23 & 0 & 0 & 8 & 6 & 0 & 0 & 0.2 \\
\hline Centropomus undecimalis & 0 & 1 & 3 & 0 & 0 & 1 & 0 & 0 & 0 & 1 & 0 & 0 & 0.0 \\
\hline Pomatomus saltatrix & 0 & 0 & 0 & 0 & 0 & 1 & 0 & 0 & 0 & 2 & 2 & 0 & 0.0 \\
\hline Caranx latus & 0 & 0 & 0 & 0 & 0 & 0 & 1 & 0 & 0 & 0 & 0 & 0 & 0.0 \\
\hline Caranx sp. & 0 & 0 & 0 & 0 & 1 & 0 & 0 & 0 & 0 & 0 & 2 & 0 & 0.0 \\
\hline Chloroscombrus chrysurus & 0 & 0 & 0 & 0 & 0 & 0 & 0 & 0 & 4 & 0 & 0 & 0 & 0.0 \\
\hline Oligoplites saurus & 0 & 0 & 0 & 0 & 0 & 20 & 2 & 0 & 0 & 1 & 2 & 0 & 0.1 \\
\hline Selene vomer & 0 & 0 & 0 & 0 & 0 & 0 & 0 & 0 & 0 & 0 & 3 & 0 & 0.0 \\
\hline Trachinotus sp. & 0 & 0 & 0 & 0 & 0 & 0 & 0 & 0 & 0 & 0 & 3 & 0 & 0.0 \\
\hline Diapterus rhombeus & 0 & 0 & 0 & 0 & 0 & 18 & 10 & 5 & 16 & 39 & 3 & 1 & 0.2 \\
\hline Eucinostomus argenteus & 8 & 8 & 2 & 8 & 4 & 96 & 13 & 7 & 2 & 0 & 0 & 1 & 0.4 \\
\hline Eucinostomus gula & 0 & 12 & 0 & 11 & 5 & 3 & 2 & 1 & 3 & 3 & 3 & 1 & 0.1 \\
\hline Eucinostomus melanopterus & 0 & 0 & 0 & 0 & 0 & 2 & 0 & 0 & 6 & 0 & 0 & 11 & 0.1 \\
\hline Bairdiella ronchus & 168 & 64 & 4 & 210 & 85 & 902 & 322 & 190 & 794 & 569 & 16 & 65 & 9.2 \\
\hline Cynoscion acoupa & 0 & 0 & 0 & 0 & 0 & 0 & 0 & 0 & 1 & 3 & 0 & 0 & 0.0 \\
\hline Cynoscion leiarchus & 0 & 0 & 0 & 0 & 0 & 0 & 0 & 1 & 4 & 0 & 0 & 0 & 0.0 \\
\hline Cynoscion microlepidotus & 0 & 0 & 0 & 0 & 0 & 0 & 0 & 1 & 0 & 2 & 0 & 0 & 0.0 \\
\hline Isopisthus parvipinnis & 0 & 0 & 0 & 0 & 0 & 0 & 0 & 0 & 2 & 0 & 0 & 0 & 0.0 \\
\hline Ophioscion punctatissimus & 0 & 0 & 0 & 0 & 1 & 121 & 1 & 3 & 0 & 4 & 2 & 0 & 0.4 \\
\hline Parablennius pilicornis & 0 & 0 & 1 & 0 & 0 & 0 & 0 & 0 & 0 & 0 & 0 & 0 & 0.0 \\
\hline Bathygobius soporator & 0 & 0 & 1 & 0 & 0 & 1 & 0 & 0 & 2 & 0 & 0 & 1 & 0.0 \\
\hline Gobionellus oceanicus & 0 & 0 & 0 & 0 & 0 & 0 & 1 & 0 & 0 & 0 & 0 & 0 & 0.0 \\
\hline Gobionellus smaragdus & 0 & 0 & 0 & 0 & 0 & 0 & 0 & 0 & 2 & 0 & 0 & 0 & 0.0 \\
\hline
\end{tabular}


TABLE 1 (Continued).

\begin{tabular}{|l|c|c|c|c|c|c|c|c|c|c|c|c|c|}
\hline & Aug & Sep & Oct & Nov & Dec & Jan & Feb & Mar & Apr & May & Jun & Jul & $\%$ \\
\hline Chaetodipterus faber & 0 & 0 & 0 & 0 & 1 & 2 & 0 & 0 & 0 & 0 & 0 & 0 & 0.0 \\
\hline Trichiurus lepturus & 0 & 1 & 0 & 0 & 0 & 0 & 0 & 0 & 4 & 0 & 1 & 7 & 0.0 \\
\hline Scomberomorus brasiliensis & 0 & 0 & 0 & 0 & 0 & 0 & 4 & 0 & 0 & 0 & 0 & 0 & 0.0 \\
\hline Peprilus paru & 0 & 1 & 0 & 0 & 0 & 0 & 0 & 0 & 0 & 0 & 0 & 0 & 0.0 \\
\hline Citharichthys arenaceus & 2 & 2 & 1 & 15 & 5 & 40 & 0 & 2 & 19 & 12 & 19 & 7 & 0.3 \\
\hline Citharichthys spilopterus & 7 & 4 & 10 & 36 & 20 & 60 & 9 & 8 & 38 & 32 & 55 & 13 & 0.8 \\
\hline Citharichthys sp. & 0 & 0 & 0 & 0 & 0 & 0 & 0 & 0 & 1 & 0 & 0 & 0 & 0.0 \\
\hline Achirus lineatus & 0 & 0 & 0 & 0 & 0 & 0 & 0 & 0 & 0 & 0 & 1 & 0 & 0.0 \\
\hline Symphurus tesselatus & 0 & 0 & 0 & 0 & 0 & 1 & 0 & 0 & 0 & 0 & 0 & 1 & 0.0 \\
\hline Sphoeroides greeleyi & 99 & 66 & 49 & 182 & 89 & 99 & 15 & 5 & 32 & 87 & 25 & 18 & 2.1 \\
\hline Sphoeroides testudineus & 151 & 62 & 119 & 317 & 164 & 274 & 76 & 35 & 413 & 174 & 312 & 96 & 5.9 \\
\hline Chaetodipterus faber & 0 & 0 & 0 & 0 & 1 & 2 & 0 & 0 & 0 & 0 & 0 & 0 & 0.0 \\
\hline
\end{tabular}

Through the percentage similarity analysis (SIMPER), for the similarity of $71.96 \%$ of group A, the main contributors were Atherinella brasiliensis, Eucinostomus argenteus, B. ronchus, S. greeleyi, and S. testudineus (70.89\%). Almost the same similarity (72.08\%) was observed in group B defined by cluster analysis (months), with the greatest contribution coming from the species A. parva, H. clupeola, $G$. genidens, B. ronchus, C. spilopterus, S. greeleyi, and S. testudineus $(67.28 \%)$. The mean dissimilarity between these two groups was of $40.77 \%$, due mainly to differences in the temporal pattern of occurrence of the species A. parva, H. clupeola, Opisthonema oglinum, G. genidens, Diapterus rhombeus, and B. ronchus (Table 3 ).

The cluster analysis (inverse method) based on the monthly abundance of the 23 selected species, separated the species into three groups at the similarity level of $65 \%$ (Fig. 5). United at the similarity level of $68 \%$, the species $S$. testudineus, B. ronchus, H. clupeola, and G. genidens form group A, the former two species represented by juvenile and adult individuals and the latter almost exclusively by juveniles. These species occur throughout the year in the tide channel, however there is a greater similarity in the pattern of occurrence of B. ronchus and S. testudineus (87.0\%) as they are present in large quantities during the whole year, while the species $H$. clupeola and $G$. genidens are more abundant in summer and spring (Table 1). A second group $\mathrm{B}$, formed at the similarity level of $67.5 \%$, is composed of two sub- groups. The first unites, at the similarity level of $75.0 \%$, juveniles and adults of the species $S$. greeleyi, C. spilopterus, A. brasiliensis, Citharichthys arenaceus, and Lycengraulis grossidens, present in the area throughout the year in smaller quantities than the species of group A, but in larger amounts than the juveniles and adults of the species $E$. argenteus and Eucinostomus gula that constitute the other sub-group of group B. Lastly, group C, with a similarity of $66.0 \%$, is formed by the species Sardinella brasiliensis, D. rhombeus, and $O$. oglinum, present in the samples mainly in the juvenile stage and practically absent in the spring. The latter two species were totally absent from the samples collected between August and December (Table 1). Species that present different patterns of occurrence did not group with any other species. These were Hyporhamphus unifasciatus, present in small amounts mainly from the middle of autumn to the beginning of spring; Ophioscion punctatissimus, present in the samples from the beginning of summer to the beginning of winter, especially as a single aggregation; Centropomus parallelus with a greater abundance from the middle of spring to the middle of summer; A. tricolor, almost exclusively present in two aggregations in autumn and in winter; and A. parva, absent in the area in spring and more frequent from the end of summer to the middle of winter, especially in large aggregations (Table 1, Fig. 5). The groups delineated in the dendrogram at the similarity level of $65.0 \%$ can be seen in the first two dimensions of the MDS 
analysis. The stress of 0.156 reveals a certain difficulty in representing the similarity relation- ships between the species through the distances in the graph (Fig. 5).
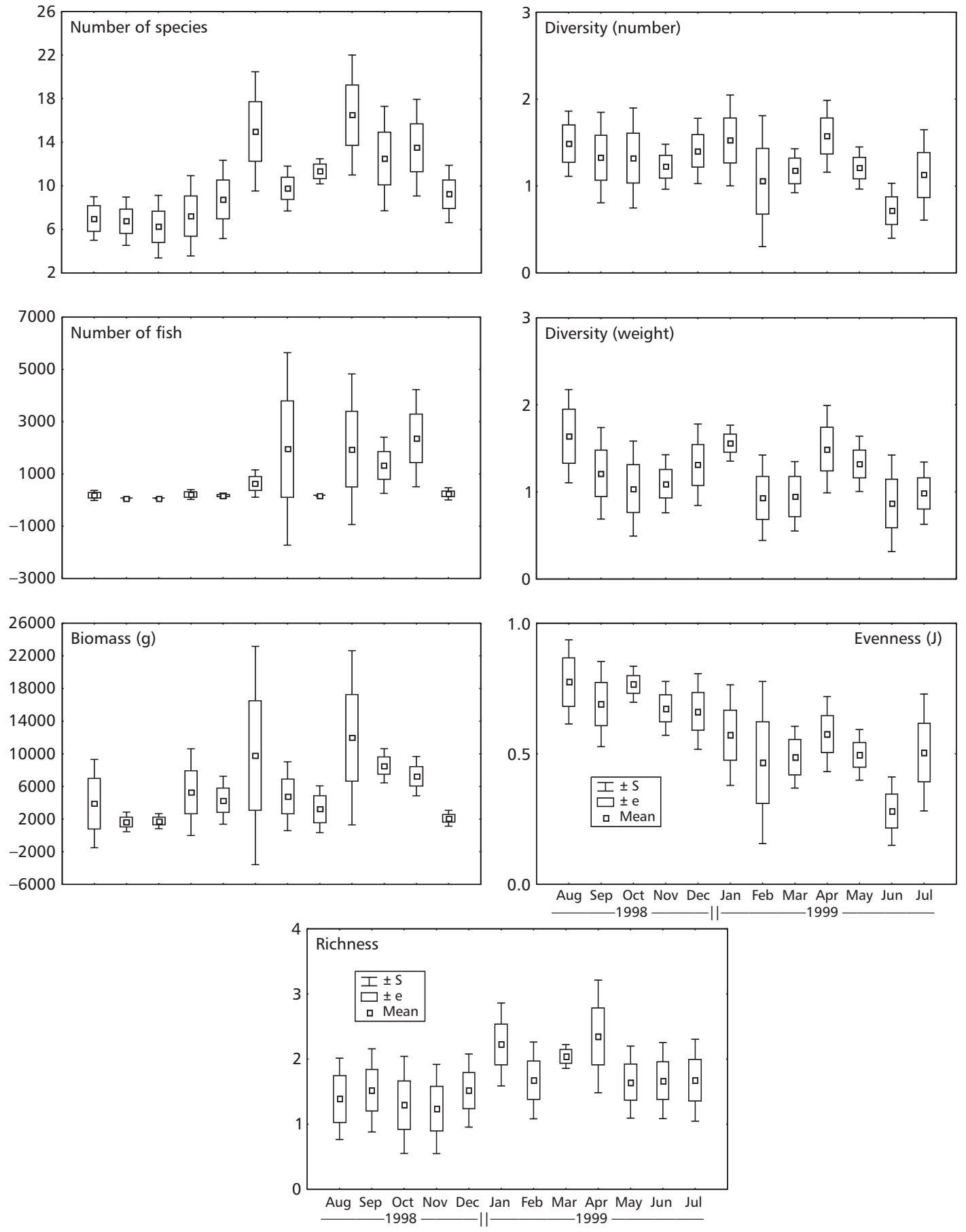

Fig. 3 - Monthly variation in the average of the number of species, number of fish, and biomass and of the richness index of Margalef, diversity index of Shannon-Wiener, and evenness index of Pielou in the Baguaçu tidal creek. 

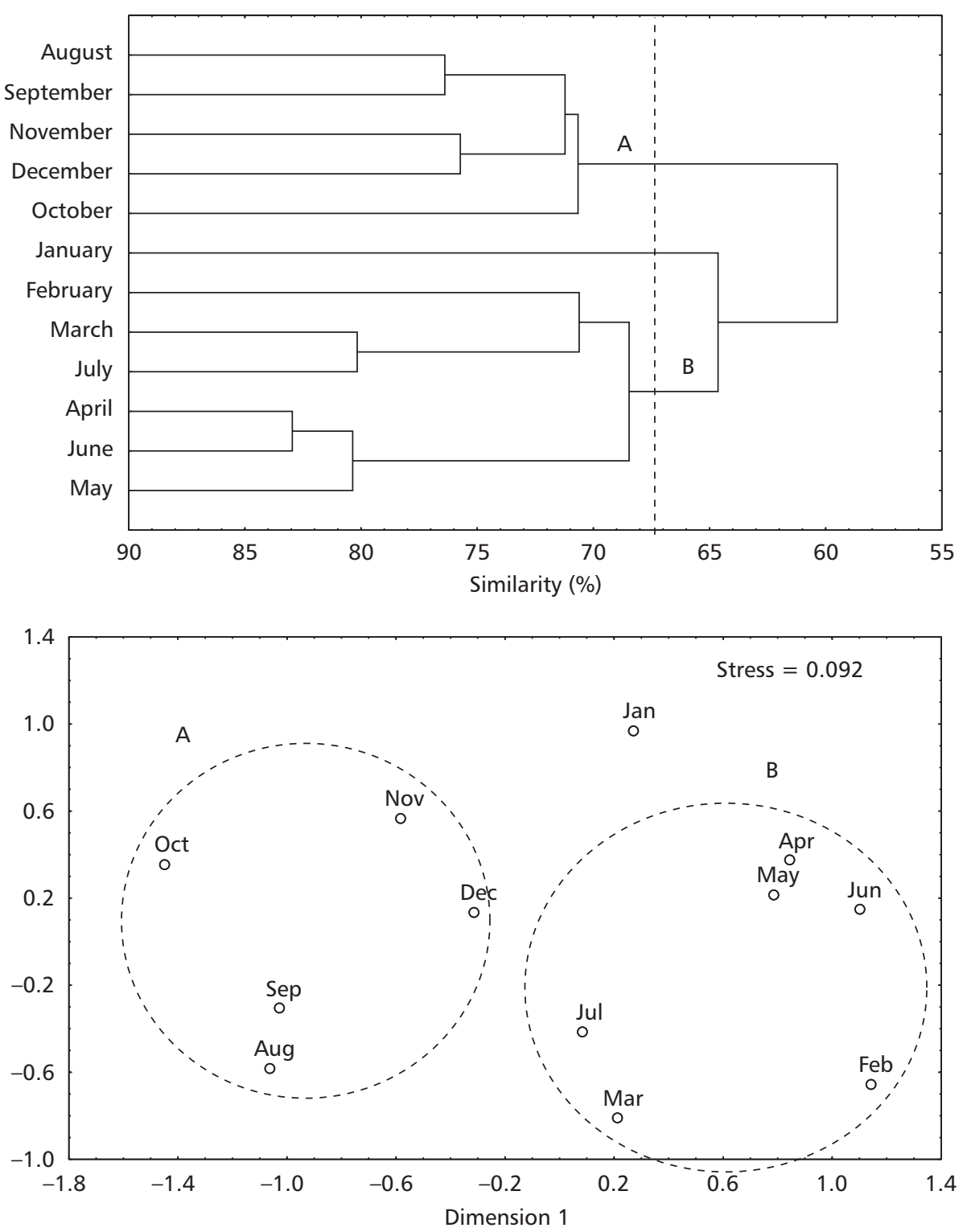

Fig. 4 - Dendrogram and MDS ordination plot based on the abundance of the main 23 taxa sampled monthly in the Baguaçu tidal creek. Groups of species delineated at the similarity level of $68 \%$ in the dendrogram, are circled in the ordination plot. The stress of the MDS ordination $=0.092$.

The probable influence of the isolated or combined physical-chemical variables on the temporal biological pattern was analyzed through the Spearman coefficient of correlation. The results revealed low correlations between the abiotic parameters and the biotic parameters analyzed (Table 4). The isolated salinity variable and the combined rainfall and $\mathrm{pH}$ variables and water transparency and $\mathrm{pH}$ variables seem to better explain the groups defined in the cluster analysis.

\section{DISCUSSION}

Studies on the fish communities of tidal creeks commonly show a small number of species contributing to a large proportion of the total capture in 
number and weight (Robertson \& Duke, 1990; Lin \& Shao, 1999; Barletta, 1999; Vidy, 2000; Laffaille et al., 2000; this study). In general, different species can dominate in a single tide channel, both in number and weight (Laffaille et al., 2000; this study), although there are cases where this dominance is exerted by the same species (Barletta, 1999; Lin \& Shao, 1999). Vendel (1997) studied the fish assemblage in the same tide channel and, although she used very different collection strategies, especially with regard to the type of net, she also observed a dominance in number and total weight of the species A. parva, H. clupeola, G. genidens, and $S$. testudineus, whereas there was a difference in the dominance of $S$. greeleyi and $B$. ronchus. Although differences exist among the localities with regard to the dominant species, this dominance is exerted by species of low trophic levels (Laffaille et al., 2000; Chaves et al., 2000; this study).
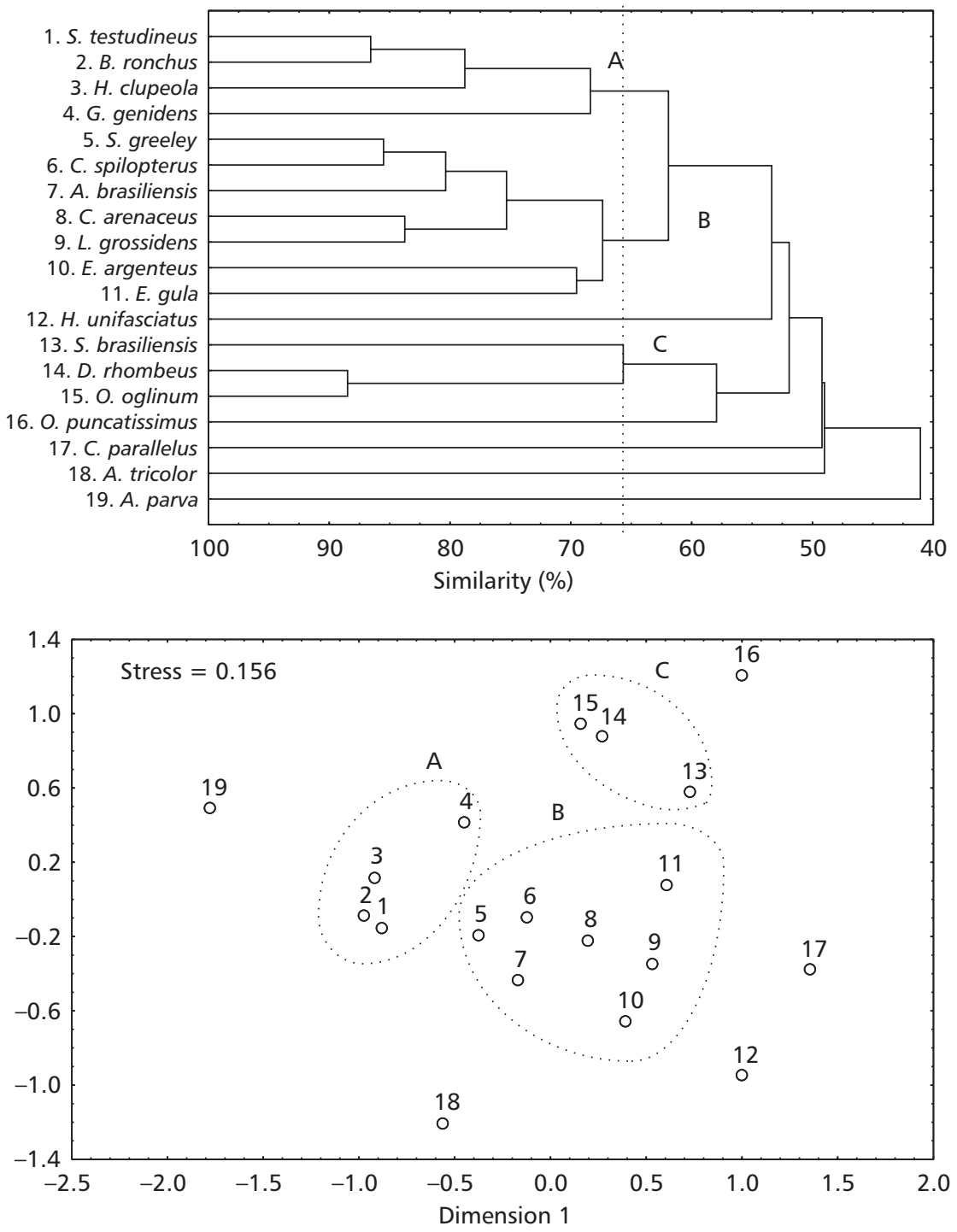

Fig. 5 - Dendrogram and MDS ordination plot showing the similarities among the most abundant taxa based on their occurrence throughout the twelve months of sampling in the Baguaçu tidal creek. Groups of species delineated at the similarity level of $65 \%$ in the dendrogram are circled in the ordination plot. In the graph, the species are represented by their respective numbers given in the dendrogram. Stress for the MDS ordination $=0.156$. 
TABLE 2

Result of the analysis of variance $(F)$ and of the Kruskal-Wallis test $(H)$, evaluating the effect of the month of collection and of the groups of months defined in the cluster analysis ( $Q$ mode), on the mean capture in number of species, number of fish, biomass, Margalef's species richness, diversity of Shannon-Wiener (number and weight), and evenness of Pielou, in the Baguaçu tidal creek (NS = non-significant difference, ** significant difference at the level of $p<0.01, *$ significant difference at the level of $\mathrm{p}<\mathbf{0 . 0 5}$, Ja $=$ January).

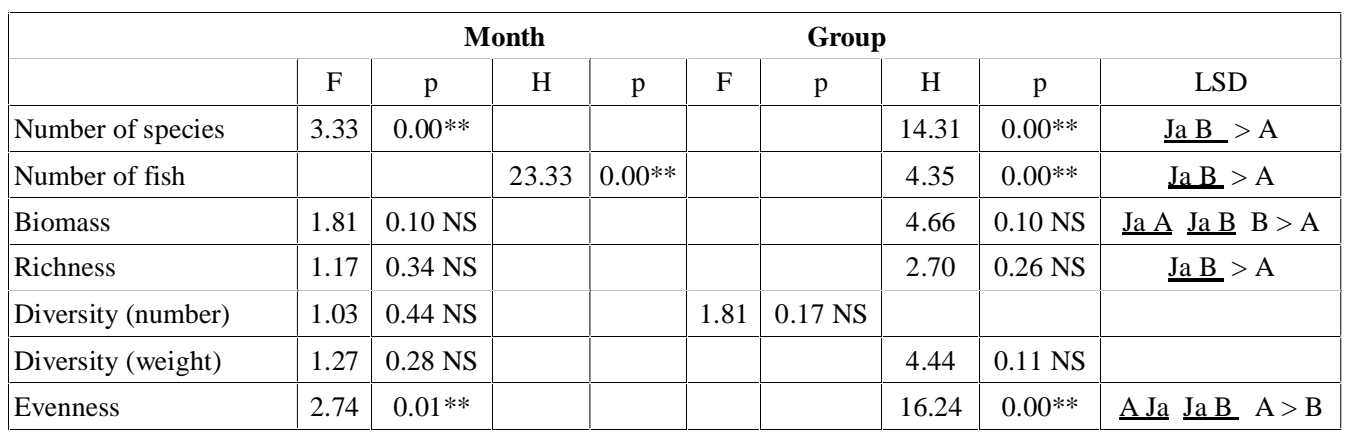

TABLE 3

Percentage contribution (\%) of the most abundant and constant species in the Baguaçu tidal creek for the similarity inside group A (August, September, October, November, and December) and group B (February, March, April, May, June, and July) and for the dissimilarity between these groups.

\begin{tabular}{|c|c|c|}
\hline & $\mathbf{A}$ & B \\
\hline Average similarity within each group (\%) & 71.96 & 72.08 \\
\hline \multicolumn{3}{|l|}{ Species } \\
\hline Anchoa parva & & 16.65 \\
\hline Lycengraulis grossidens & 6.27 & \\
\hline Harengula clupeola & & 11.88 \\
\hline Opisthonema oglinum & & 4.75 \\
\hline Genidens genidens & & 4.83 \\
\hline Atherinella brasiliensis & 8.28 & \\
\hline Diapterus rhombeus & & 4.67 \\
\hline Eucinostomus argenteus & 7.73 & \\
\hline Bairdiella ronchus & 12.91 & 10.68 \\
\hline Citharichthys arenaceus & 6.26 & \\
\hline Citharichthys spilopterus & 8.89 & 6.49 \\
\hline Sphoeroides greeleyi & 15.64 & 6.51 \\
\hline \multirow[t]{2}{*}{ Sphoeroides testudineus } & 17.44 & 10.25 \\
\hline & $\mathrm{A} \times \mathrm{B}$ & \\
\hline Average dissimilarity between groups (\%) & 40.77 & \\
\hline \multicolumn{3}{|l|}{ Species } \\
\hline Anchoa parva & 21.97 & \\
\hline Harengula clupeola & 10.15 & \\
\hline Opisthonema oglinum & 6.50 & \\
\hline Genidens genidens & 6.82 & \\
\hline Diapterus rhombeus & 6.26 & \\
\hline Bairdiella ronchus & 5.04 & \\
\hline
\end{tabular}


TABLE 4

Most significant results of rank correlation (BIOENV), indicating the influence of the water temperature (T), salinity $(S), p H(p)$, water transparency (Tr), current speed $(C)$, and rainfall $(R)$ on the community pattern. The values are the coefficients of pondered harmonic Spearman rank correlation, for the isolated variables and each combination. The results indicate the nature and the magnitude of the correlation.

\begin{tabular}{|c|c|c|c|c|}
\hline $\mathbf{S}$ & $\mathbf{R}$ & $\mathbf{R p}$ & Trp & STr \\
\hline-0.166 & -0.107 & -0.186 & -0.166 & -0.149 \\
\hline RTrp & STrp & RSTrp & TrSTrp & TRSTrpV \\
\hline-0.155 & -0.149 & -0.134 & -0.116 & -0.073 \\
\hline
\end{tabular}

A characteristic of the fish populations in shallow coastal areas is the abundance of juveniles in the captures. This dominance demonstrates the importance of shallow water environments such as mangrove forests, tidal pools, rocky shores, coastal reefs, beach surf zones, and estuaries, for the nursering of fish. In the captures at Baguaçu, the juvenile specimens constituted $65 \%$ of the captured fish and $96 \%$ of the species were represented by juveniles. The species Gobionellus oceanicus and Gobionellus smaragdus were only present in the samples as adults. The species B. ronchus, S. testudineus, S. greeleyi, $C$. arenaceus, and $C$. spilopterus seemed to occupy the area throughout the year, while the species $A$. parva, G. genidens, S. brasiliensis, H. clupeola, $C$. parallelus, D. rhombeus, Oligoplites saurus, $O$. oglinum, and Anchoa lyolepis appear in the area as juvenile migrants, and $O$. punctatissimus as a migrant both in the juvenile and adult stages. Most of the fish community at Baguaçu was formed by occasional visitors, mainly juveniles of marine species (34 species), a common pattern in tidal creeks (Lin \& Shao, 1999; Vidy, 2000). The species E. argenteus, E. gula, and A. brasiliensis, visibly abundant in the juvenile stage in the external marginal areas of Paranaguá Bay (Godefroid et al., 1997; Pinheiro, 1999; Lopes, 2000), were captured in the tide channel in significant amounts during the whole year, although they showed an irregular pattern of occurrence. Chaves \& Otto (1999) verified that species of Eucinostomus present in the mangroves of Guaratuba Bay use the area for part of their life cycle, with the juveniles growing throughout the year then migrating to other areas for maturation and spawning in spring and summer.

Part of the variability found in the data (abundance and diversity), as already mentioned, might depend on the collection method, which is easily observed if we compare the results obtained by Vendel (1997) with this study. Besides the differences observed in the relative abundance of the dominant species, 13 and 16 species were exclusive to the first and second study, respectively. Species such as Eucinostomus melanopterus, Cynoscion acoupa, Cynoscion leiarchus, Cynoscion microlepidotus, $O$. punctatissimus, Trichiurus lepturus, S. brasiliensis, C. spilopterus, Hemiramphus brasiliensis, and Isopisthus parvipinnis, present in significant amounts only in this study, were probably absent in the previous study as they are largely associated with the saline front in the high tide and/or they move together with the tide along the deepest part of the tide channel, conditions that were only considered in the sampling strategy of the present study. This fact seems to agree with Corrêa's observations (1987), that these species, with the exception of $O$. punctatissimus and $H$. brasiliensis that were not mentioned in these studies, are associated principally with the main channel of the estuary and the adjacent continental shelf, areas where the more saline coastal waters prevail.

The seasonal cycle of the number of species in the tide channel, with significantly larger averages from the middle of summer to the middle of winter, and peaks in January, April, and June, where the largest number of occasional species occur, mainly in the juvenile stage, demonstrates that in this period the area is used largely for nursering. This was also observed in a previous study in Baguaçu, Paraná (Vendel, 1997) and in tidal creeks of Pará State (Barletta, 1999), Australia (Robertson \& Duke, 1990), and France (Laffaille et al., 2000). In Paranaguá Bay and in other regions of the southeasternsouthern coast of Brazil, this seasonal pattern occurred in several studies about the ichthyofauna 
of different coastal shallow water environments (Chao et al., 1982; Lopes, 2000).

In Paranaguá Bay, studies on the fish communities showed a larger abundance of individuals in the summer and autumn and smaller in the winter and spring (Pinheiro, 1999). This seasonal pattern is repeated in Baguaçu tidal creek, with peaks of occurrence in February, April, May, and June, caused by large captures of juveniles of A. parva, H. clupeola, $B$. ronchus, and G genidens, species responsible for more than $90 \%$ of the total capture in these months. Vendel (1997), in a survey of Baguaçu, also observed, in the summer and autumn, large aggregations of $A$. parva, H. clupeola, B. ronchus, and G. genidens especially of the first species that, as in this study, was the most abundant species in the tide channel. An explanation for this pattern is that the tide channel was dominated by the resident estuarine species $A$. parva, B. ronchus, G. genidens, $S$. greeleyi, and $S$. testudineus (Chaves et al., 2000) and the marine species H. clupeola, with similar life histories. The resident ones spawned at the site or close to the area in the spring and summer, and the marine species in the adjacent coastal zone (Chaves, 1989, 1995; Rocha et al., 2002; Schultz et al., 2002), with the recruitment occurring mainly between the summer and beginning of winter. Reproduction in the spring and summer, with subsequent recruitment in the summer and autumn has been observed in most of the local species (Pinheiro, 1999; Chaves \& Otto, 1999; Chaves \& Bouchereau, 2000).

In the warmest seasons of the year, the greater penetration of the more nutrient-rich South Atlantic central water (SACW) on the internal continental shelf causes an increase in the primary production of the euphotic zone and in the stability of the column, that together with the smaller turbulence of the mixture layer maintains the food aggregates in such a way as to favor the fish larvae. Moreover, the predominant direction of the wind favors the transport of larvae by passive drift towards the coast, where they aggregate in areas adjacent to estuaries before migrating to recruitment areas. In spite of the continental drainage, Paranaguá Bay is dominated by the adjacent coastal water and all the hydrological events in the shelf affect the temporal dynamics of the nutrients and the phytoplankton (Brandini \& Thamm, 1994). Therefore, these intrusions of the SACW increase the total biomass of phytoplankton in Paranaguá
Bay, making food more available for the fish and favoring the nursering and recruitment processes in the area during this period. The dominance of few species of primary consumers, a common fact in estuarine areas (Blaber et al., 1984), characterizes the prevalence of short food chains able to sustain a high density of fish in the system. The juveniles of $A$. parva and $H$. clupeola, probably in their first year, corresponded to $69 \%$ of the annual production and, through their planktotrophic diet, these fish are the main direct connection with the high primary production in the region. Other species such as $G$ genidens, B. ronchus, C. arenaceus, C. spilopterus, $S$. greeleyi, and $S$. testudineus, also important numerically, are mainly carnivorous at the base of the food chain and are, therefore, favored by the increment of the secondary production in the area (Chaves \& Vendel, 1996; Chaves \& Serenato, 1998; Vendel \& Chaves, 1998).

Diversity and richness indices have been used as an aid in interpretating the temporal patterns in fish assemblages. In the present study, the richness index of Margalef showed considerable change in the richness of species, there being significantly larger values between January and July in comparison to the rest of the year, with no seasonal tendency having been observed in any other shallow environment at Paranaguá Bay (Godefroid et al., 1997; Lopes, 2000). The richness (D) at Baguaçu was between 0.2 and 3.54. These values are relatively different from those observed in the surf zone at Pontal do Sul beach (D = 2.0-5.05, Godefroid et al., 1997), and in a tidal flat close to the study area ( $\mathrm{D}=1.35-3.7$; Lopes, 2000).

The values of $\mathrm{H}^{\prime}$ for total weight were very close to the $\mathrm{H}^{\prime}$ for number, and neither showed seasonal dynamics. This absence of a seasonal change in the specific diversity was also observed in other studies of fish populations in the region (Godefroid et al., 1997; Lopes, 2000). In Baguaçu, the diversity in number, expressed by the index of Shannon-Wiener, varied between the minimum of 0.24 in February and the maximum of 2.17 in April. These values are very close to those observed by Lopes (2000) in a tidal flat at the entrance of the tide channel and by Godefroid et al. (1997) at a beach not very distant from the area. The width of the $\mathrm{H}^{\prime}$ variation reflected the great number of seasonal and occasional species that use these localities as a seasonal base, however, the low values 
reflected the dominance of few species. The population indexes reflected changes in the abundance of the species and the individuals at every moment of the sample period. The diversity $\left(\mathrm{H}^{\prime}\right)$ and the evenness $(\mathrm{J})$ presented similar patterns of fluctuation during the 12 months. The richness index (D), however, showed a different pattern, indicating that the species richness and the evenness, both of which are components of diversity, followed different tendencies through time.

The fish community of Baguaçu was dominated by periodic and resident components, all primary consumers, that made up three groups of species. The first group had two estuarine species (S. testudineus and G. genidens) and two marine species (B. ronchus and H. clupeola). The second group included seven species, six of which are estuarine species ( $S$. geeleyi, C. spilopterus, $A$. brasiliensis, $C$. arenaceus, E. argenteus, and $E$. gula) the remaning species is a marine one (L. grossidens). The third group had three marine one (S. brasiliensis, $D$. rhombeus, and O. oglinum). Among the species that did not group in the cluster analysis, only $\mathrm{H}$. unifasciatus can be considered an estuarine species, while the others are all marine (O. punctatissimus, C. paralelus, A. tricolour, and A. parva). The comparison of the local ichthyofauna and especially the dominance ratio, seems to reflect the change in estuarine and marine conditions. Although this tide channel is situated in the euhaline section of Paranagua Bay, it alternates between being an actual estuarine condition at low tide and a marine one at high tide, conditions that were included in the collection plan.

\section{REFERENCES}

BARLETTA, M., 1999, Seasonal changes of density, biomass and species composition of fishes in different habitats of the Caeté estuary (Northern Brazilian coast - east Amazon). Zentrum für Marine Tropenökologie - ZMT, 7, 115p.

BLABER, S. J. M., HAY, D. G., CYRUS, D. P. \& MARTÍN, T. J., 1984, The ecology of two degraded estuaries on the north coast of Natal, South Africa. S. Afr. J. Zool., South Africa, 19: 224-240.

BRANDINI, F. P. \& THAMM, C. A. C., 1994, Variações diárias e sazonais do fitoplâncton e parâmetros ambientais na Baía de Paranaguá. Nerítica, Curitiba, 8(1-2): 55-72.

CATTRIJSSE, A., MAKAWAIA, E. S., DANKWA, H. R., HAMERLYNCK, O. \& HEMMINGA, M. A., 1994, Nekton communities of an intertidal creek of a European estuarine brackish marsh. Mar: Ecol. Prog. Ser., Oldendorf, 109: 195208.
CHAO, L. N., PEREIRA, L. E., VIEIRA, J. P., BEMVENUTI, M. A. \& CUNHA, L. P. R., 1982, Relação preliminar dos peixes estuarinos e marinhos da Lagoa dos Patos e região costeira adjacente, Rio Grande do Sul, Brasil. Atlântica, Rio Grande, 5: 67-75.

CHAVES, P. T. C., 1989, Desenvolvimento de ovócitos em Harengula clupeola, Urophycis brasiliensis, Eucinostomus argenteus, Isopisthus parvipinnis e Menticirrhus americanus (Teleostei). Bol. Inst. Oceanogr., São Paulo, 37(2): 81-93.

CHAVES, P. T. C., 1995, Atividade reprodutiva de Bairdiella ronchus (Cuvier) (Pisces, Sciaenidae) na Baía e Guaratuba, Paraná, Brasil. Rev. Bras. Zool., Curitiba, 12(4): 759-766.

CHAVES, P. T. C. \& BOUCHEREAU, J-L., 2000, Use of mangrove habitat for reproductive activity by the fish assemblage in the Guaratuba Bay, Brazil. Oceanologica Acta, 23(3): 273-280

CHAVES, P. T. C., BOUChEREAU, J. L. \& VENDEL, A. L., 2000, The Guaratuba Bay, Paraná, Brazil (2552'S; 48³9'W), in the life cycle of coastal fish species. In: International Conference Sustainability of Estuaries and Mangroves: Challenges and Prospects, Recife. Published in CD-rom by UFRPE. Recife, pp. 1-8. 1 CD-ROM.

CHAVES, P. T. C. \& OTTO, G., 1999, The mangrove as a temporary habitat for fish: the Eucinostomus species at Guaratuba Bay, Brazil (2552'S; 48³9'W). Braz. Arch. Biol. Tecnol., Curitiba, 42(1): 61-68.

CHAVES, P. T. C. \& SERENATO, A., 1998, Diversidade de dietas na assembléia de linguados (Teleostei, Pleuronectiformes) do manguezal da Baía de Guaratuba, Paraná, Brasil. Rev. Bras. Oceanogr., São Paulo, 46(1): 61-68.

CHAVES, P. T. C. \& VENDEL, A. L., 1996, Aspectos da alimentação de Genidens genidens (Valenciennes) (Siluriformes, Ariidae) na Baía de Guaratuba, Paraná. Rev. Bras. Zool., Curitiba, 13(3): 669-675.

CLARKE, K. R. \& WARWICK, R. W., 1994, Change in marine communities: an approach to statistical analysis and interpretation. Plymouth Marine Laboratory, 859p.

CONOVER, W. J., 1990, Practical nonparametric statistics. John Willey \& Sons, New Jersey, 584p.

CORRÊA, M. F. M., 1987, Ictiofauna da Baía de Paranaguá e adjacencias (litoral do Estado do Paraná - Brasil). Levantamento e produtividade. Dissertação de Mestrado, UFPR, Curitiba, 460p.

DESMOND, J. S., ZEDLER, J. B. \& WILLIAMS, G. D., 2000 , Fish use of tidal creek habitats in two Southern California salt marshes. Ecol. Engineering, 14: 233-252.

GODEFROID, R. S., HOFSTAETTER, M. \& SPACH, H. L., 1997, Structure of the fish assemblage in the surf zone beach at Pontal do Sul, Paraná. Neritica, Curitiba, 11: 77-93.

LAFFAILLE, P., FEUNTEUN, E. \& LEFEUVRE, J. C., 2000, Composition of fish communities in a European macrotidal salt marsh (the Mont Saint-Michel Bay, France). Estuar. Coast. Shelf Sci., London, 51: 429-438.

LIN, H. J. \& SHAO, K. T., 1999, Seasonal and diel changes in a subtropical mangrove fish assemblage. Bull. Mar. Sci., 65(3): 775-794 
LOPES, S. C. G., 2000, Ictiofauna de uma planicie de mare adjacente à Gamboa do Baguaçu, Baía de Paranaguá. Monografia de Bacharelado, UFPR, Curitiba, 35p.

LUDWIG, J. A. \& REYNOLDS, J. F., 1988, Statistical ecology. John Wiley \& Sons, 337p

PATERSON, A. W. \& WHITFIELD, A. K., 2000, Do shallow water habitats function as refugia for juvenile fishes? Estuar: Coast. Shelf Sci., London, 51: 359-364.

PINHEIRO, P. C., 1999, Dinâmica das comunidades de peixes em três áreas amostrais da Ilha do Mel, Baía de Paranaguá, Paraná, Brasil. Dissertação de Mestrado, UFPR, Curitiba, $171 \mathrm{p}$.

ROBERTSON, A. L. \& DUKE, S. J. M., 1990, Mangroves as nursery sites: comparisons of the abundance and species composition of fish and crustaceans in mangroves and other nearshore habitats in tropical Australia. Mar. Biol., New York, 96: 193-205.

ROCHA, C., FÁVARO, L. F. \& SPACH, H. L., 2002, Biologia reprodutiva de Sphoeroides testudineus (Linnaeus, 1758), Tetraodontidae, da Gamboa do Baguaçu, Baía de Paranaguá, Pr. Rev. Bras. Zool., Curitiba, 19(1): 57-63.

ROZAS, L. P. \& ZIMMERMAN, R. J., 2000, Small-scale patterns of nekton use among marsh and adjacent shallow nonvegetated areas of the Galveston Bay Estuary, Texas (USA). Mar. Ecol. Prog. Ser., Oldendorf, 193: 217-239.
SCHULTZ, Y. D., FÁVARO, L. F. \& SPACH, H. L., 2002, Aspectos reprodutivos de Sphoeroides greeleyi (Gilbert, 1900), Tetraodontidae, da Gamboa do Baguaçu. Paranaguá, PR. Rev. Bras. Zool., Curitiba, 19(1): 65-76.

SESSEGOLO, G. C. S., 1997, Estrutura e produção de serapilheira do manguezal do Rio Baguaçu, Baía de Paranaguá-PR. Dissertação de Mestrado, UFPR, Curitiba, $130 \mathrm{p}$.

SOKAL, R. R. \& ROHLF, F. J., 1995, Biometry. W. H. Freeman and Company, $859 \mathrm{p}$

VENDEL, A. L., 1997, Dinâmica e estrutura da assembléia de peixes na gamboa do Baguaçu, Baía de Paranaguá, Paraná. Monografia de Bacharelado, UFPR, Curitiba, 44p.

VENDEL, A. L. \& CHAVES, P. T. C., 1998, Alimentação de Bairdiella ronchus (Curvier) (Perciformes, Sciaenidae) na Baía de Guaratuba, Paraná, Brasil. Rev. Bras. Zool., Curitiba, 15(2): 297-305

VIDY, G, 2000, Estuarine and mangrove systems and the nursery concept: which is which? The case of the Sine Saloum system (Senegal). Wetlands Ecology and Management, 8: 37-51. 